\title{
Responses to Covid-19 from Kiwi hospitallers
}

\section{Lindsay Neill and Nigel Hemmington}

Dr Lindsay Neill is a senior lecturer in hospitality management at Auckland University of Technology, New Zealand. Lindsay holds research interests in vernacular culture, food, identity, and popular culture.

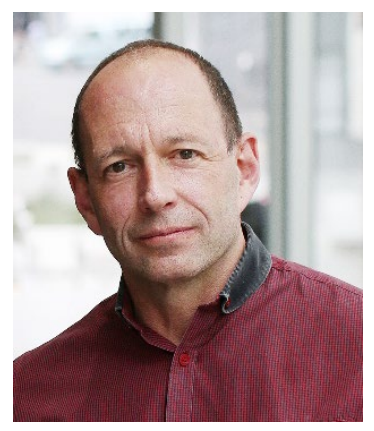

Nigel Hemmington was formerly pro vice-chancellor at Auckland University of Technology. His research interests are in the areas of strategic hospitality management, consumer behaviour and consumer experience, and philosophies of hospitality.

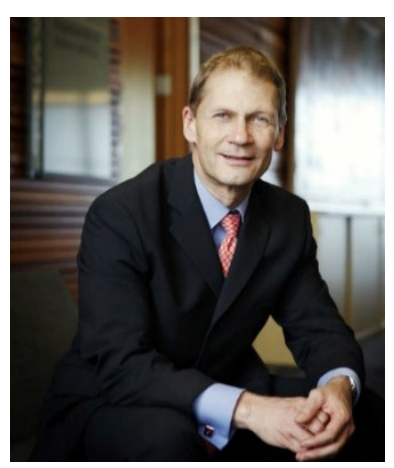

The global impact of COVID-19 has been dramatic and research into that impact is beginning to emerge within the tourism and hospitality literature. The research reflects both theoretical and geo-graphical/regional perspectives. Some examples are as follows:

- an exploration of the impact of COVID-19 on the hotel industry in China considering disaster management [1];

- research into the nexus of COVID-19 and hospitality resilience [2];

- the impact of COVID-19 on the Indian tourism and hospitality industry [3];

- an analysis of how COVID-19 has impacted restaurant firms' stock market returns in the United States of America [4].

In Aotearoa New Zealand, during September 2020, we conducted research with 11 providers of hospitality who were responsible for a total of 105 food and beverage outlets. Those outlets comprised of 22 cafés, 4 restaurants and 79 takeaways. The longevity of our 105 participant businesses averaged 11 years and three months. Their locations ranged from Auckland, the Central Plateau, Christchurch, Dunedin, and Invercargill. Our participant businesses are detailed in Table 1.

Table 1: Details of the 11 participants and their businesses

\begin{tabular}{lcccc}
\hline $\begin{array}{l}\text { Market } \\
\text { segment }\end{array}$ & $\begin{array}{c}\text { Participant's } \\
\text { role }\end{array}$ & $\begin{array}{c}\text { Number } \\
\text { of outlets }\end{array}$ & $\begin{array}{c}\text { Years in } \\
\text { business }\end{array}$ & $\begin{array}{c}\text { Company annual } \\
\text { income (\$) }\end{array}$ \\
\hline Cafés & Owner & 1 & 7.5 & $900 \mathrm{k}-1 \mathrm{~m}$ \\
& Director & 20 & 24 & $250 \mathrm{k}-2 \mathrm{~m}$ \\
& CEO/owner & 1 & 13 & No response \\
\hline Restaurants & Owner & 1 & 6 & $2.8-3 \mathrm{~m}$ \\
& Owner & 1 & 2 & $2.8-3 \mathrm{~m}$ \\
& Owner & 1 & 11 & $1.5-1.8 \mathrm{~m}$ \\
& Owner & 1 & 3 & $700-750 \mathrm{k}$ \\
\hline Takeaways & CEO & 1 & 22 & No response \\
& Owner & 1 & 3 & $270-300 \mathrm{k}$ \\
& Owner & 1 & 13 & $2 \mathrm{~m}$ \\
& Brand manager & 76 & 17 & $4-4.5 \mathrm{~m}$ \\
\hline
\end{tabular}

We located several themes that were important to our participants; four of them are discussed below. 


\section{Theme 1: The economic impact of COVID-19}

Turnover was down, and businesses had experienced reduced spending per head. However, countering that was the realisation within some businesses that COVID-19 also represented opportunities for innovation. Those opportunities were driven by factors that included the increased business use of social media, and human contact (albeit at a distance). Because customers were socially distanced, ordering from home and consequent home deliveries represented opportunities for business growth and renewal. Additionally, COVID-19 changed the labour market from an employee-driven model to one benefitting employers. Key to that was the Government's wage subsidy scheme.

\section{Theme 2: Government policy and COVID-19}

There was not universal participant support for the Government's COVID-19 policies. For many respondents, working through policy proved stressful. Participant dissatisfaction was fuelled by comparisons to the Australian Government's hospitality initiatives. Yet, despite that, our participants also realised that New Zealand's 'severe' COVID-19 response placed the nation in a positive position for a quick business recovery.

\section{Theme 3: Government COVID-19 recovery/assistance packages}

Our participants anticipated that normal business would return with 18-36 months. However, they also noted that more government interventions were needed. Participants cited the helpful measures undertaken in the Christchurch earthquakes, and again cited the Australian Government's initiatives as being particularly helpful. Additionally, our participants were hopeful that a transTasman 'bubble' was key in stimulating business growth. Labour-based initiatives were also mentioned, particularly the easing of visa restrictions for workers in the hospitality industry. Similarly, a directory matching potential employees and employers and giving new workers 'a go' within a 90-day trial period were popular options.

\section{Theme 4: Business initiatives and recovery from COVID-19}

COVID-19 highlighted the importance of hospitality's basic ethos: caring for others within acts of hospitality. Our participants recognised that consumer patterns were changing. Within those changes our participants re-evaluated and embraced menu change, fostered a sense of community with customers either in real or virtual time, and spent time in self-reflection. Those actions, particularly reflection, generated for our participants a new sense of 'self' within their business. That renewed sense of self included the disconnection of hospitality from international tourism. Simply put, the international tourist market was extinct: local Kiwis were 'the market'. That realisation enhanced our participants' sense of community and inspired them to create more local and long-term connections.

For many participants, COVID-19 realised a pragmatic renewed appreciation and understanding of something obvious: the local market. Consequently, our exploration of COVID-19's impact on our participant groups not only provides a unique insight into their business considerations of COVID-19, but also reflects positive attributes of our nation's wider socio-culture and psyche. 


\section{Corresponding author}

Lindsay Neill can be contacted at: lindsay.neill@aut.ac.nz

\section{References}

(1) Hao F.; Xiao, Q.; Chon, K. COVID-19 and China's Hotel Industry: Impacts, a Disaster Management Frame-work, and Post-Pandemic Agenda. International Journal of Hospitality Management 2020, 90, 102636. https://doi.org/10.1016/j.ijhm.2020.102636

(2) Alonso A.; Kok S.; Bressan, A. COVID-19, Aftermath, Impacts, and Hospitality Firms: An International Perspective. International Journal of Hospitality Management 2020, 91, 102654. https://doi.org/10.1016/j.ijhm.2020.102654

(3) Kaushal, V.; Srivastava, S. Hospitality and Tourism Industry amid COVID-19 Pandemic: Perspectives on Challenges and Learnings from India. International Journal of Hospitality Management 2021, 92, 102707. https://doi.org/10.1016/j.ijhm.2020.102707

(4) Song H.; Yeon, J.; Lee, S. (2021). Impact of the COVID-19 pandemic: Evidence from the U.S. Restaurant Industry. International Journal of Hospitality Management 2021, 92, 102702. https://doi.org/10.1016/j.ijhm.2020.102702 